\title{
Historical perspectives of The American Association for Thoracic Surgery: Evarts A. Graham (1883-1957)
}

\author{
Thomas A. D'Amico, MD
}

Evarts Ambrose Graham, the 10th president of The American Association for Thoracic Surgery (AATS), was born in Chicago on March 19, 1883 (Figure 1). He graduated from Princeton in 1904, where he developed his deep interest in surgery: "To do major surgery, to engage in research work, and to have a clinic of younger men who would be interested in studying and developing ideas." ${ }^{1}$ He subsequently received his medical degree in 1907 from Rush Medical College, where his father was on the surgical faculty. He then cut an atypical pathway to a surgical career. After medical school, he spent 1 year in a pathology fellowship, after which he worked several years in independent study of chemistry and physiology. Nevertheless, he began in private practice general surgery in 1915, but that experience-his observation of ghost surgery and fee-splitting-was disappointing and unsettling. He resolved to address these problems of private practice surgery and eventually did so later in his career as a regent of the American College of Surgeons. ${ }^{1}$

\section{EARLY ACHIEVEMENTS}

The global influenza pandemics of 1917 and 1918 caused more than half a million deaths in the United States alone. When the United States entered World War I, influenza in the crowded barracks of military camps became a crippling problem with the development of secondary bacterial pneumonia caused by group A streptococci, characterized by hemorrhagic pleural effusion progressing to empyema. The high mortality rate associated with empyema in American soldiers made it essential to improve the treatment of this disease urgently. In early 1918, the Surgeon General established the Empyema Commission to address this problem, and that same year, when Dr Graham entered the United States Army as a major, he was appointed to serve on this commission. Throughout the remainder of his career, Dr Graham considered himself as a general surgeon with expertise in the chest, in chief owing his experiences with the Empyema Commission during World War I. ${ }^{2}$

\footnotetext{
From the Department of Surgery, Duke University Medical Center, Durham, NC. Disclosures: Author has nothing to disclose with regard to commercial support. Received for publication June 5, 2011; accepted for publication June 28, 2011; available ahead of print Aug 8, 2011

Address for reprints: Thomas A. D'Amico MD, Professor of Surgery, Duke University Medical Center, Box 3496, Duke South, White Zone, Room 3589, Durham, NC 27710 (E-mail: damic001@mc.duke.edu).

J Thorac Cardiovasc Surg 2011;142:735-9

$0022-5223 / \$ 36.00$

Copyright (c) 2011 by The American Association for Thoracic Surgery doi:10.1016/j.jtcvs.2011.06.028
}

The concepts of negative intrapleural pressure and vital capacity were formulated into Graham's explanation of the high mortality rate associated with open drainage of patients with streptococcal empyema. Graham and his associates developed an algorithm dictating repeated aspirations of the pleural fluid with delayed open drainage, followed by sterilization of the empyema cavity. Of the 22 patients under Graham's care who survived this treatment, 13 healed completely and the remaining were at various stages of healing. The mortality rate decreased to less than $5 \%$, and other camps reported similar results when they abandoned early open drainage during the pneumonic stage. ${ }^{2}$ For this pioneering work, Graham was awarded the prestigious Samuel D. Gross Prize from the Philadelphia Academy of Surgery in 1920.

During his tour of duty, Dr Graham did not always conform to the military hierarchy. For example, when the only water source in the small French village where his unit was later stationed was found to be contaminated with typhoid, Graham independently determined that his commanding colonel had been negligent in making appropriate changes. Averting the usual hierarchy, Dr Graham reported this problem directly to the Commander General of the European Theater. ${ }^{2}$

In 1919, after completing his tour of duty at the age of 36 , Graham was appointed as the first full-time professor of surgery and chairman of the Department of Surgery at Washington University School of Medicine. He was only the second full-time professor of surgery in the entire United States, the first being William S. Halsted, who had been appointed 5 years earlier as the full-time chair of surgery at Johns Hopkins. His last chief resident, C. Barber Mueller, described him vividly: "Graham was a big, tall and dignified man who, to his residents, seemed to be approximately eight feet in height."

Graham's association with Warren Cole, another resident and later his research and staff associate, was unique and productive, and it led to a lifelong friendship between the two men. ${ }^{4}$ During his surgical residency, Cole was assigned by Graham to work in his laboratory as a research fellow in 1923. In 1924, Cole published the first of a series of papers on the first successful radiographic visualization of the gallbladder, using an oral contrast agent. Cholecystography became known as the Graham-Cole test, and this discovery achieved international fame, a discovery that Dr Alfred Blalock ${ }^{5}$ believed worthy of the Nobel Prize. Cole later left St Louis in 1936 to head the department of surgery at the University of Illinois for the next 30 years. 


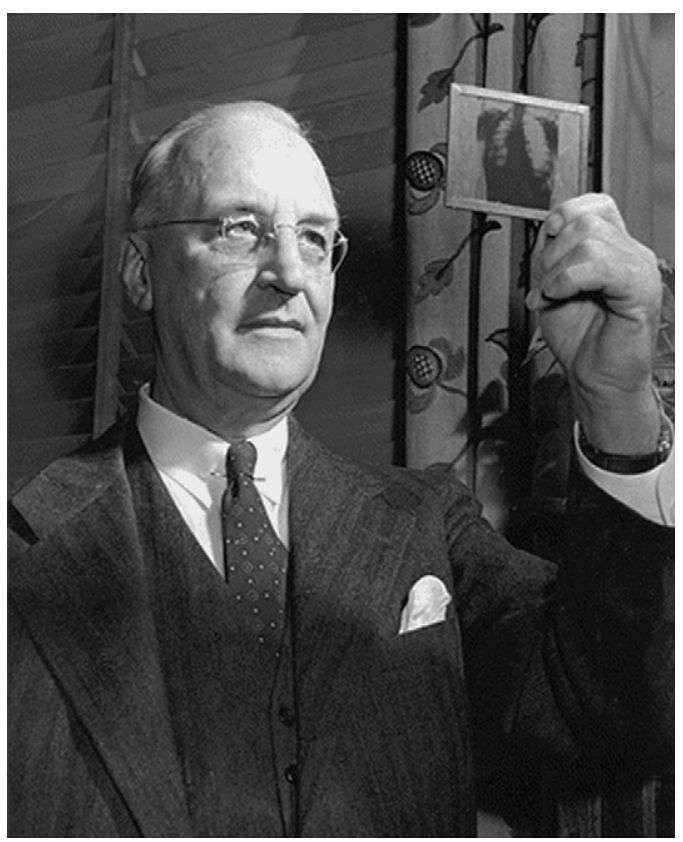

FIGURE 1. Dr Evarts A. Graham. (Courtesy of the Becker Medical Library, Washington University School of Medicine, St Louis, Mo.)

\section{THE PNEUMONECTOMY}

On April 5, 1933, Dr Graham performed the first successful 1-stage pneumonectomy for lung cancer, an accomplishment that he believed was his greatest surgical contribution. Dr James Gilmore, a 48-year-old obstetrician-gynecologist from Pittsburgh, sought out Dr Graham after recently having been diagnosed with lung cancer. ${ }^{6}$ Gilmore had had chronic cough and fever for 7 months before seeking consultation with Graham. ${ }^{7,8}$ Bronchoscopy revealed a tumor the "size of a pea" located at the opening of the upper lobe bronchus, and biopsy demonstrated squamous cell carcinoma. $^{7}$ On learning he had cancer and would most likely require a lobectomy, Gilmore delayed the operation. He returned home to consider his options, had dental work performed, and even purchased a cemetery plot. Unaware of the cemetery plot, Graham would later praise Gilmore's decision to have dental work as an indication of his patient's optimism and confidence; only many years later would Graham learn of Gilmore's cemetery plot purchase. ${ }^{9}$

Gilmore soon returned to St Louis for surgery. On entering Gilmore's chest, Graham determined that pneumonectomy would be required, but he was concerned that the patient would not tolerate sudden occlusion of the pulmonary artery. "...I told the anesthetist that I was planning to obstruct the pulmonary artery suddenly and I wanted to be told if any changes occurred in the pulse, respirations or color of the patient. I then passed a small rubber catheter around the artery, which would obstruct the artery when I pulled on the ends of the catheter, but which could be released instantly if any trouble arose." ${ }^{, 9}$ After 90 seconds, and the patient remaining stable, Graham believed it was safe to continue. He then removed the lung by first tying a "small rubber catheter tightly around the hilus as close to the trachea as possible" after which "crushing clamps were placed on the hilus below the catheter and the lung was cut off with an electric cautery knife." 10 The bronchial stump was then closed with chromic catgut, and radon seeds were inserted into various parts of the stump.

The procedure took only 1 hour 45 minutes. An episode of hypotension at the start of the surgery was treated with glucose and acacia. ${ }^{10}$ Gilmore maintained an excellent blood pressure for the remainder of the procedure (Figure 2). Pathologic examination demonstrated that the tumor was a stage II squamous cell carcinoma: T2 N1 (Figure 3). After a prolonged hospital course, Gilmore was discharged and did reasonably well. He returned to Pittsburgh and resumed his practice for 24 years after the pneumonectomy. He also continued to smoke. When $\mathrm{Dr}$ Gilmore died on March 6, 1963, there was no evidence of recurrent or residual lung cancer. ${ }^{8}$

Within weeks of the operation, Graham attended the annual conference of the AATS. At the meeting, Graham mentioned Gilmore's operation, including the successful result. ${ }^{11}$ The news of Graham's success spread rapidly around the world. Mountain ${ }^{12}$ later commented "...it was not only one case. It was the leaven that stimulated and invigorated the whole field of lung surgery; it was the essential catalyst that set in train the development of the modern treatment of lung cancer."

In his first published report of the procedure, Graham actually credited Hermann Kümmell, a German surgeon, as having performed the first 1-stage pneumonectomy. ${ }^{13}$ However, Kümmell's report lacked sufficient surgical detail, and the patient did not survive. Years later, the subject of "the first pneumonectomy" arose again. After a report by Graham $^{7}$ for the Texas Cancer Bulletin in 1949, in which he took credit for having performed the first pneumonectomy, Dr John Alexander wrote to the editor requesting that Graham be asked to write a correction to show that "the first successful pneumonectomy was performed by Rudolph Nissen in Berlin in 1931, the second by Cameron Haight in Ann Arbor in 1932, and the third by Evarts A. Graham in St. Louis in 1933." Graham later explained that both Nissen and Haight performed the procedure in 2 stages, ligating the hilar vessels in the first stage and removing the lung in the second stage. Thus, it is now agreed that Dr Graham's case was the first 1-stage procedure and was the first successful pneumonectomy for lung cancer. ${ }^{9}$

Over the course of his surgical career, Graham's scientific achievements were numerous and impressive. His work with the Empyema Commission in 1918 was estimated to have saved thousands of lives, and his discovery of a method for imaging the gallbladder was thought to possibly warrant a Nobel Prize in Medicine. Moreover, Graham played an 


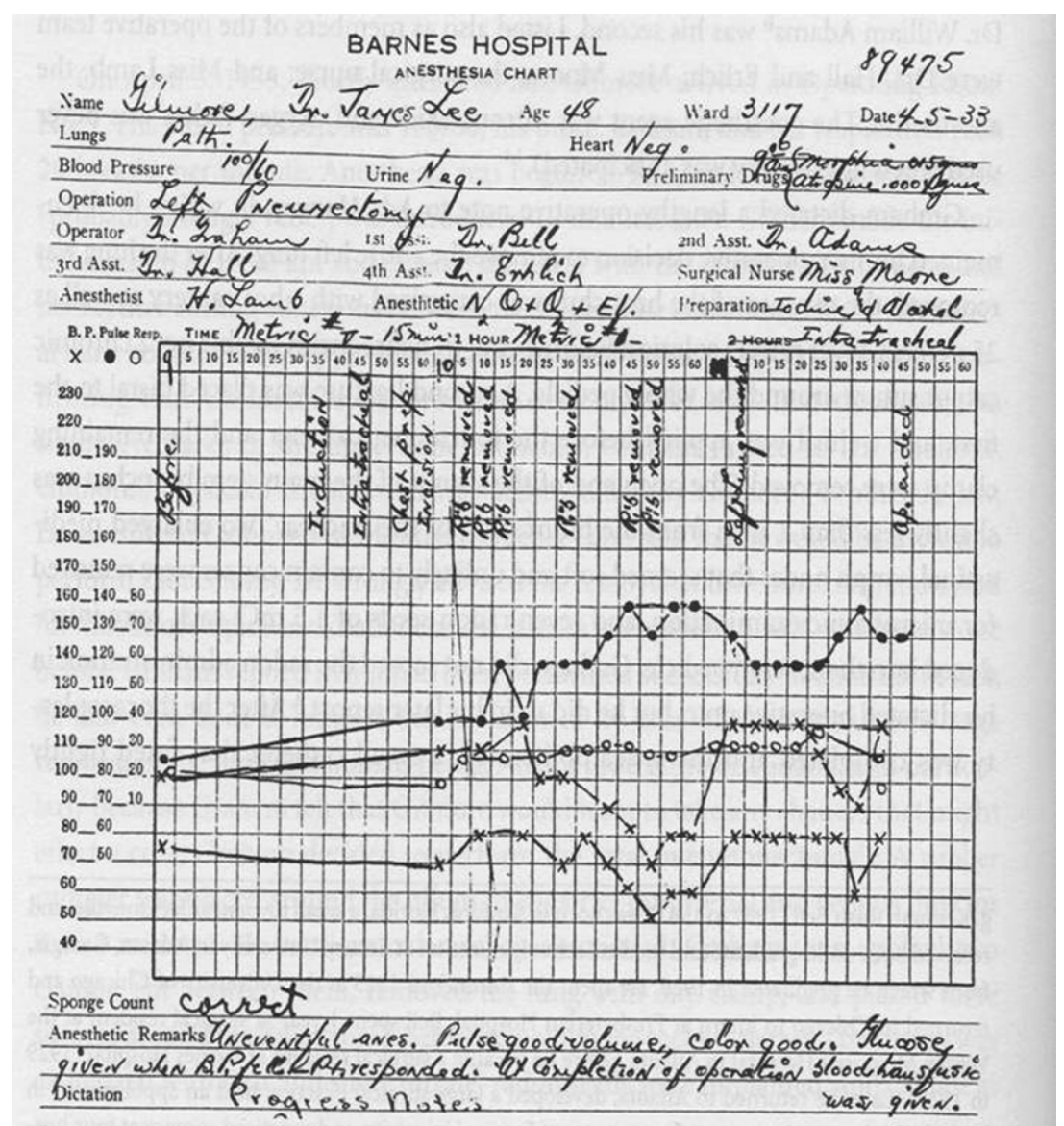

FIGURE 2. Anesthesia record from the first successful pneumonectomy. (Reprinted with permission from Mueller BC. Evarts A. Graham: The life, lives, and times of the surgical spirit of St. Louis. Hamilton (ON): BC Decker; 2002:124.)

important role in the development of thoracic surgical training in the United States, and he was the first to statistically prove the markedly increased risk of lung cancer in cigarette smokers. ${ }^{14}$ Yet, Dr Graham believed that the pneumonectomy was his most important achievement. He clearly recognized the historical significance of his accomplishment, as evidenced by his expedient effort to publish his case report. ${ }^{10}$ In the next 5 years after the Gilmore pneumonectomy, Graham would perform 70 such procedures for malignancies, with only 3 operative deaths in the last 25 cases. ${ }^{12}$ In 1942, he was awarded the Lister Medal for his contributions to surgical science. ${ }^{15}$ The corresponding Lister oration, "Some Aspects of Bronchiogenic Carcinoma," was delivered at the Royal College of Surgeons of England in 1947. ${ }^{16}$

Ironically, Graham himself was an avid smoker. Although initially skeptical about the association of cigarette smoking and lung cancer, he engaged in several research projects designed to elucidate this relationship. His study with Ernest Wynder in 1950 was the first to demonstrate an epidemiologic relationship between tobacco and lung cancer. ${ }^{13}$ This discovery was followed by several laboratory experiments demonstrating that cigarette tars could cause cancer. ${ }^{17}$
Nevertheless, Dr Graham continued to smoke. At age 73, continuing to feel unwell after an episode of the flu in late 1956, Graham went for a checkup at Barnes Hospital, where a chest $\mathrm{x}$-ray film revealed bilateral lung lesions. ${ }^{18}$ To establish a diagnosis, Graham submitted to a scalene node biopsy and was found to have a small cell lung cancer. He underwent a course of nitrogen mustard on February 1, $1957 .{ }^{19}$ Two weeks later, Graham had hip pain. A radiograph revealed lytic bone lesions in the head of the right femur and acetabulum for which "betatron" treatment was administered. ${ }^{18}$ On February 6, 1957, Graham dispassionately wrote to his collaborator in the study of lung cancer, Ernest Wynder: "Dear Ernie. I suppose you have heard by this time from one source or another about the irony that fate has played on me...I was anxious for you to be one of the first ones to know about my illness because of my great interest in you and because of our long and happy cooperation in the enterprise of trying to defeat the enemy who seems to have got the best of me now." On the morning of February 26, Graham became confused while shaving; he was admitted to Barnes Hospital for the last time. On March 4, 1957, Evarts Ambrose Graham died of metastatic small cell lung cancer. 


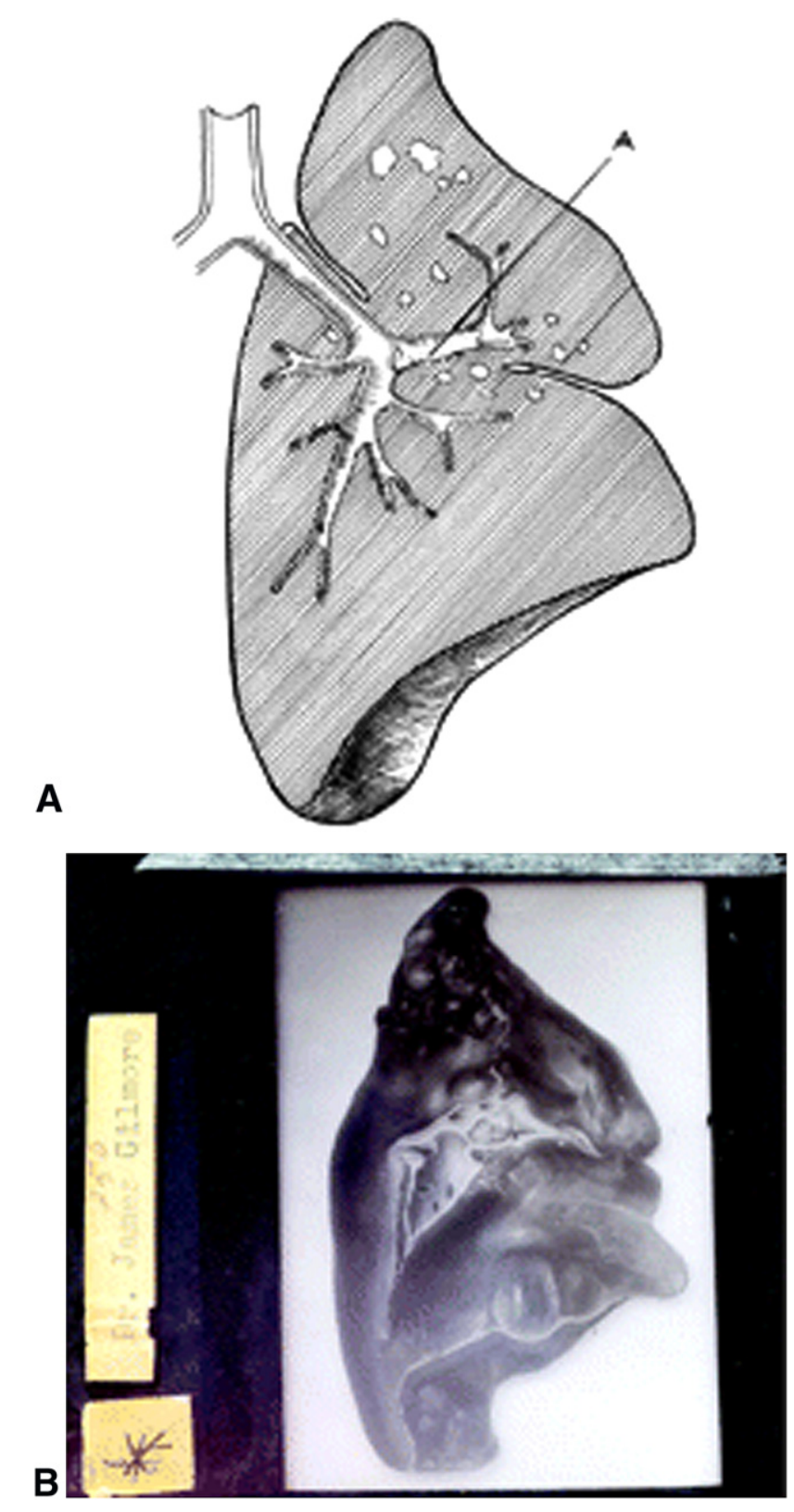

FIGURE 3. A, Medical illustration depicting the location of Gilmore's lung cancer. (Reprinted with permission. ${ }^{10}$ ) B, Note the suppurative nodules in upper lobe. (Courtesy of the Becker Medical Library, Washington University School of Medicine, St Louis, Mo.)

One of Graham's last deathbed visitors was James Gilmore, and his death note timed 3:38 PM was cosigned by two future AATS presidents: Thomas H. Burford, 51 st AATS president, and Thomas B. Ferguson, 62nd AATS president.

\section{ACADEMIC ASSOCIATIONS}

Over the years, Graham was an active member of 17 societies, president of 5, and an honorary member in 29 others. As evidence of his career-long effort to improve the standard of medical care, he served for 14 years as a member of the Medical Fellowship board of the National Research Council, and he served as the chair of its Committee on Surgery from 1940 to 1946 . He also served on the President's Commission on the Health Needs of the Nation and on the Medical Task Force of the first Hoover Commission. He was instrumental in the founding of the American Board of Surgery in 1937.

One of Dr Graham's most significant contributions was his personal involvement with the AATS and its publishing organ, the Journal of Thoracic Surgery. Dr Graham was elected to membership of the Association in 1920, at the third annual meeting in Chicago, becoming the 83rd member. During these early years, the Association began to grow and thrive, and Dr Graham was elected president of the Association in 1928. His presidential address- "Remarks on the Significance of Changed Intrathoracic Pressure" - was delivered on May 1, 1928, at the 11th annual meeting in Washington, DC. Ironically, the entire academic session preceding his address was dedicated to lung cancer, a prelude to his presidential address and to his most significant surgical accomplishment. In 1931, the Journal of Thoracic Surgery was established, and Dr Graham was appointed as its first editor, a position he held until his death in 1957.

Evarts Ambrose Graham, the Association's 10th president and the Journal's first editor, was an overpowering physical figure and surgical leader. He dominated American surgery during the middle third of the 20th century and had a substantial influence on American surgery spanning 3 decades. Each of his accomplishments-the study of empyema, the development of cholecystography, the improvement of surgical training, and the discovery of tobacco's role in the epidemiology of lung cancer-would alone signify a successful career as a surgical scholar. Taken together, his contributions represent an overwhelming body of work. Yet, in addition to these achievements, Dr Graham's crowning accomplishment seems to best define his legacy: the first successful 1-stage pneumonectomy for lung cancer.

Lord Russell Brock ${ }^{20}$ remarked that Graham exemplified what really constituted greatness in a surgeon: "Is success based purely on technical ability, or does it lie in the scientific, detached, and original mind capable of introducing new thoughts and methods? ... [This was] one of the great lessons of Graham's life and work." Joseph Hinsey, ${ }^{21}$ speaking at Graham's memorial service, commented, "There have been three surgeons who have profoundly influenced the progress of surgery in our country in this century: Halstead, Cushing, and Graham."

\section{References}

1. Mueller BC. Backgrounds and beginnings. In: Evarts A. Graham: the life, lives, and times of the surgical spirit of St. Louis. Hamilton (ON): BC Decker; 2002:15-7.

2. Mueller BC. World War I. In: Evarts A. Graham: the life, lives, and times of the surgical spirit of St. Louis. Hamilton (ON): BC Decker; 2002:36-46. 
3. Mueller BC. Washington University and Barnes Hospital. In: Evarts A. Graham: the life, lives, and times of the surgical spirit of St. Louis. Hamilton (ON): BC Decker; 2002:71-99.

4. Connaughton D. Warren Cole, $M D$, and the ascent of scientific surgery. Champaign (IL): University of Illinois Press; 1991:123.

5. Blalock A. Dr. Evarts Ambrose Graham and American surgery. Bull Am Coll Surg. 1957;42:222-5.

6. Horn L, Johnson DH. Evarts A. Graham and the first pneumonectomy for lung cancer. J Clin Oncol. 2008;26:3268-75.

7. Graham EA. The first total pneumonectomy. Tex Cancer Bull. 1949;2:2-4.

8. Baue AE. Landmark perspective: Evarts A. Graham and the first pneumonectomy. JAMA. 1984;251:260-4.

9. Mueller CB. The pneumonectomy. In: Evarts A. Graham: the life, lives, and times of the surgical spirit of St. Louis. Hamilton (ON): BC Decker; 2002:117-40.

10. Graham EA, Singer JJ. Successful removal of an entire lung for carcinoma of the bronchus. JAMA. 1933;101:1371-4.

11. Lilienthal H. Pneumonectomy for sarcoma of lung in a tuberculous patient. $J$ Thorac Surg. 1933;2:600-15.
12. Mountain CF. The evolution of the surgical treatment of lung cancer. Chest Surg Clin North Am. 2000;10:83-104.

13. Mountain CF, Hermes KE. Surgical treatment of lung cancer: past and present Methods Mol Med. 2003;75:453-87.

14. Wynder EL, Graham EA. Tobacco smoking as a possible etiologic factor in bronchiogenic carcinoma: a study of 684 proved cases. JAMA. 1950;143:329-36.

15. Announcement of the award of the Lister Medal. Nature. 1941;148:500.

16. Graham EA. Some aspects of bronchiogenic carcinoma. Ann R Coll Surg Engl. 1947;1:248-64.

17. Wynder EL. A corner of history: micro-epidemiology. Prev Med. 1973;2: 465-71.

18. Mueller CB. Illness and finale. In: Evarts A. Graham: the life, lives, and times of the surgical spirit of St. Louis. Hamilton (ON): BC Decke; 2002:391-400.

19. Gellhorn A. Reminiscences from my medical school and residency days. Perspect Biol Med. 2004;47:32-46.

20. Brock R. Evarts A Graham. Ann Thorac Surg. 1970;9:272-9.

21. Hinsey JC. Evarts Ambrose Graham [brochure]. St. Louis: Washington University; 1957. Address delivered at Evarts A. Graham memorial service; p. 10-11. 